\title{
Performance Improvements of Bixin and Metal-Bixin Complexes Sensitized Solar Cells by 1-Methyl-3-propylimidazolium Iodide in Electrolyte System
}

\author{
Winda Rahmalia ${ }^{{ }^{*}}$, Septiani ${ }^{1}$, Uray Amira Naselia ${ }^{1}$, Thamrin Usman ${ }^{1}$, \\ Imelda Hotmarisi Silalahi ${ }^{1}$, and Zéphirin Moulounguii ${ }^{2,3}$ \\ ${ }^{1}$ Department of Chemistry, Faculty of Mathematics and Natural Sciences, Tanjungpura University, \\ Jl. Ahmad Yani, Pontianak 78124, West Kalimantan, Indonesia \\ ${ }^{2}$ Laboratoire de Chimie Agro-industrielle (LCA), Université de Toulouse, INP-ENSIACET, \\ 4 Allée Emile Monso, 31030 Toulouse, France
}

${ }^{3}$ INRA, UMR 1010 CAI, F-31030 Toulouse, France

\section{* Corresponding author:}

tel: $+62-561-577963$

email:winda.rahmalia@chemistry.untan.ac.id

Received: October 15, 2020

Accepted: December 13, 2020

DOI: $10.22146 / \mathrm{ijc} .60633$

\begin{abstract}
Bixin is one of the potential natural sensitizers used in dye-sensitized solar cells (DSSCs). In this study, bixin was complexed with Cu(II) and Zn(II) to increase its stability. The formation of the complexes was indicated by shifting peaks absorption and the changes in the fine spectral structure observed from the $U V$-Vis absorption spectra. The metal-bixin complex occurs due to the interaction between the ester groups of bixin and the metal. Bixin, Cu-bixin, and Zn-bixin were used separately as sensitizers in DSSCs. The DSSCs performance was then improved by adding 1-methyl-3-propylimidazolium iodide (MPII) to the electrolyte system. The presence of MPII $0.4 \mathrm{M}$ in KI-I $\mathrm{I}_{2}$ electrolyte produced a higher ionic conductivity value $\left(20.44 \mathrm{mS} \mathrm{cm}^{-1}\right)$ than that without MPII (11.14 $\left.m S \mathrm{~cm}^{-1}\right)$. This electrolyte system significantly improved DSSCs performance. Under a light intensity of $300 \mathrm{~W} / \mathrm{m}^{2}$, the maximum energy conversion efficiencies of DSSC with bixin, Cu-bixin, and Zn-bixin as sensitizers are 0.084, 0.081, and $0.005 \%$, respectively. The Zn-bixin-based DSSC was stable under high light intensity. Under $700 \mathrm{~W} / \mathrm{m}^{2}$, its maximum energy conversion efficiency reaches $0.125 \%$. There was a synergistic work observed between the metal-bixin complex and the MPII based electrolyte. This result can open the way for constructing functional materials for solar cell applications.
\end{abstract}

Keywords: bixin; complex; dye-sensitized solar cells (DSSCs); 1-methyl-3propylimidazolium iodide (MPII)

\section{- INTRODUCTION}

Dye-sensitized solar cells (DSSCs) are a third generation of the photovoltaic cell. It is a low-cost solar cell belonging to thin-film solar cells due to inexpensive constituent materials and a simple fabrication process [12]. Dye sensitizer is one of the essential components of DSSCs [3]. Organic or natural dyes-based sensitizers offer a suitable alternative to high-cost inorganic dyes. Ruthenium and several materials used as inorganic dye sensitizers are also toxic and low natural abundance [4].
Among naturally occurring carotenoids, bixin (methyl hydrogen 9'-cis-6,6'-diapocarotene-6,6'-dioate, $\mathrm{C}_{25} \mathrm{H}_{30} \mathrm{O}_{4}$, CAS Number: 39937-79-5) is a potential dye that has been explored as a sensitizer in DSSCs because of its 9'-cis structure and two carboxylic groups, one of which is a methyl carboxy ester as shown in Fig. 1(a). The bixin's carboxylic group can react readily with the metal oxide's surface hydroxyl groups [5-7]. Bixin can absorb UV-A, UV-B, and UV-C with absorption coefficients in aprotic polar solvents of over $10^{4} \mathrm{M}^{-1} \mathrm{~cm}^{-1}[5,8]$, which is 


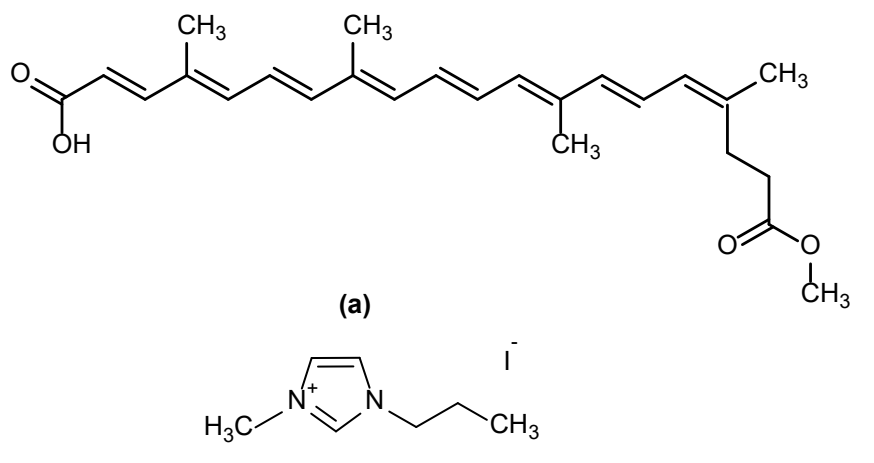

(b)

Fig 1. Structure of cis-bixin (a) and 1-methyl-3-propyl imidazolium iodide (MPII) (b)

an advantage for dyes as sensitizers in DSSCs. However, due to their conjugated double bonds system, the stability of natural sensitizers like bixin in DSSCs is debated [9].

De Sousa Lobato et al. [10] have conducted research to increase bixin stability by using polymer encapsulation to produce bixin nanocapsules. This method was able to increase the stability of bixin up to $100 \pm 0.02 \%$. However, encapsulation could inhibit the role of bixin as a sensitizer. Another way to increase the stability of the dye sensitizer is the complexation method. This method can prevent cloudiness or loss of color from the dye. Cortez et al. [11] reported that metal ions used in complex processes were shown to stabilize the dye extract color. Besides that, the oxidation state of metal ions plays a vital role in forming dye-metal complexes. Therefore, complexes of bixin with divalent transition metal ions $\left(\mathrm{Zn}^{2+}\right.$ and $\left.\mathrm{Cu}^{2+}\right)$ were prepared. In a coordination complex, the transition group metals tend to act as a Lewis acid (an electron acceptor). They are bonded by ligands which act as Lewis bases (an electron donor) [12-13]. The different electronic properties of these two transition metals $\left(\mathrm{Cu}^{2+}, \mathrm{Zn}^{2+}\right)$ are interesting to study because they will show different interactions with ligands in organometallic complexes [14-15].

In addition to the sensitizer stability, electrolyte stability also has an essential role in improving the DSSCs performance. The electrolyte is a charge transport medium produced by sensitizer and photoanode. The electrolyte system that has been widely used is the liquid electrolyte type of the redox $\mathrm{I}^{-} / \mathrm{I}^{3-}$ pair. Rahmalia [12] fabricated DSSC with a bixin-based sensitizer using liquid electrolyte $\mathrm{KI}-\mathrm{I}_{2}$, showing a maximum performance of $0.08 \%$. The low viscosity of liquid electrolytes makes it easy for the solvent to leak or evaporate, thereby drastically reducing performance.

Shi et al. [15] have reported that electrolyte stability can be improved by adding an additive ionic liquid such as imidazolium. This leads to an increase in the conductivity and energy conversion efficiency of the DSSC system. Ionic conductivity increases with increasing electrolyte density due to the increased concentration of free ions formed after adding imidazolium to the liquid electrolyte [16]. One of the imidazolium groups is 1-methyl-3-propylimidazolium iodides (MPII, Fig. 1(b)). The concentration of ionic liquid added to the electrolyte system affects the viscosity, conductivity, and mobility of electrons. Therefore, this study discusses the effect of MPII concentrations in the $\mathrm{KI}-\mathrm{I}_{2}$ electrolyte system on the performance of bixin and bixin-metal complexes sensitized solar cells, focused on short circuit current (Isc), open-circuit voltage (Voc), and the maximum energy conversion efficiency.

\section{- EXPERIMENTAL SECTION}

\section{Materials}

Kesumba (Bixa orellana L.) seeds were obtained from West Kalimantan Indonesia, $\mathrm{NH}_{4} \mathrm{OH}$-activated metakaolinite prepared by Rahmalia et al. [17]. Acetone $\left(\mathrm{CH}_{3} \mathrm{COCH}_{3}, \geq 99.9 \%\right)$ was supplied by Mallinckrodt Chemicals, iodine $\left(\mathrm{I}_{2}\right)$ by VWR Chemicals, plastisol by Solaronix, transparent conductive oxide (TCO) glass with fluorine-doped tin oxide (FTO) type thermal evaporation coating, $7-8 \mathrm{ohm} / \mathrm{sq}$ (TEC-7) conductive glass by SOLEM. Anatase nanopowder titanium dioxide $\left(\mathrm{TiO}_{2}<25 \mathrm{~nm}\right.$ particle size, $99.7 \%$ trace metals basis) and 1-methyl-3propylimidazolium iodide (MPII) were supplied by Sigma Aldrich. Acetonitrile $\left(\mathrm{C}_{2} \mathrm{H}_{3} \mathrm{~N}, \geq 99.8 \%\right)$, ethyl acetate $\left(\mathrm{C}_{4} \mathrm{H}_{8} \mathrm{O}_{2}, \geq 99.9 \%\right)$, potassium iodide $(\mathrm{KI})$, copper sulfate $\left(\mathrm{CuSO}_{4} \cdot \mathrm{xH}_{2} \mathrm{O}\right)$, zinc sulfate $\left(\mathrm{ZnSO}_{4} \cdot \mathrm{H}_{2} \mathrm{O}\right)$, triton-x-100 $\left(\mathrm{C}_{8} \mathrm{H}_{17} \mathrm{C}_{6} \mathrm{H}_{4}\left(\mathrm{OCH}_{2} \mathrm{CH}_{2}\right)_{\mathrm{n}} \mathrm{OH}\right)$, acetylacetone $\left(\mathrm{C}_{5} \mathrm{H}_{8} \mathrm{O}_{2}\right)$ absolute ethanol $\left(\mathrm{C}_{2} \mathrm{H}_{5} \mathrm{OH}\right)$, and aluminium thin layer chromatography plate, silica gel coated with fluorescent indicator F254 (TLC F ${ }_{254}$ ) were supplied by Merck. 


\section{Procedure}

\section{Preparation of bixin and metal-bixin complexes}

Preparation of bixin. Kesumba seeds (75 g) were immersed in $200 \mathrm{~mL}$ of ethyl acetate in an Erlenmeyer flask, stirred for $1 \mathrm{~h}$, and filtered. The process was repeated until all the colors are extracted into the ethyl acetate solution, and it was then evaporated at $40{ }^{\circ} \mathrm{C}$ to give $6.9 \mathrm{~g}$ of crude residue (9.4\%). The $2 \mathrm{~g}$ crude residue was chromatographed over silica gel $60 \AA$ (70-230 mesh) using hexane, mixtures of hexane-ethyl acetate $(9: 1,8: 2,7: 3,6: 4$, $1: 1$ ), acetone, a mixture of acetone-methanol (1:1), and methanol. The eluates were collected, monitored by thinlayer chromatography, and combined in major fractions. Bixin ( $0.13 \mathrm{~g})$ was obtained from the last fractions.

Preparation of complexes $\mathbf{M}$-bixin ( $\mathbf{M}=\mathbf{Z n}(\mathrm{II})$ and $\mathrm{Cu}(\mathrm{II}))$. $\mathrm{ZnSO}_{4} \cdot \mathrm{H}_{2} \mathrm{O}$ and $\mathrm{CuSO}_{4} \cdot \mathrm{xH}_{2} \mathrm{O}$ were separately heated at $100{ }^{\circ} \mathrm{C}$ for $24 \mathrm{~h}$ to remove hydrates. The complex of $\mathrm{Zn}$-bixin was prepared as follows. An aqueous solution of $\mathrm{Zn}$ (II) (12.2 mg in $1 \mathrm{~mL}$ of distilled water) was added gradually into bixin solution $(30.0 \mathrm{mg}$ in $30 \mathrm{~mL}$ of acetone), then stirred until homogeneous. The mixture was refluxed for $1 \mathrm{~h}$. It was evaporated on heating in an oven at $50{ }^{\circ} \mathrm{C}$ for $2 \mathrm{~h}$ to remove the solvent. The powder complex of $\mathrm{Zn}$-bixin was obtained and stored in the dark at $4{ }^{\circ} \mathrm{C}$ until further treatment. The $\mathrm{Cu}$-bixin complex was prepared by the same method by replacing $\mathrm{Zn}$ (II) with $\mathrm{Cu}$ (II) (12.3 $\mathrm{mg}$ in $1 \mathrm{~mL}$ of distilled water) and bixin solution (30.5 $\mathrm{mg}$ in $30 \mathrm{~mL}$ of acetone). The bixin (Bx), $\mathrm{Zn}$-bixin $(\mathrm{Zn}-\mathrm{Bx})$, and $\mathrm{Cu}$-bixin $(\mathrm{Cu}-\mathrm{Bx})$ complexes were analyzed by a double-beam Shimadzu UV-1800 UV-Vis and a Shimadzu FT-IR spectrophotometer.

\section{Fabrication of dye-sensitized solar cells (DSSCS) Preparation of transparent conductive oxide (TCO).} TEC7 FTO glasses measuring $2.5 \times 2.0 \mathrm{~cm}^{2}$ were washed using soap and water. The glasses were immersed in $70 \%$ ethanol using a bath sonicator for $30 \mathrm{~min}$, then dried at a temperature of $100{ }^{\circ} \mathrm{C}$ for $1 \mathrm{~h}$. The conductive side of the glasses was determined.

Preparation of anode. Photoanode was prepared by adopting the method of Rahmalia [12]. The mixture of anatase- $\mathrm{TiO}_{2}(2.375 \mathrm{~g})$ and a mixture of ammoniaactivated metakaolinite (MKA, $0.126 \mathrm{~g}$ ) were added with $15 \mathrm{~mL}$ of absolute ethanol, 16 drops of triton-x, and 12 drops of acetylacetone. The mixture was then stirred for $24 \mathrm{~h}$ to form a paste. The photoanode paste formed was sonicated for $3.0 \mathrm{~h}$.

Preparation of electrolytes. The electrolyte used in this study is a redox pair $\left(\mathrm{I}^{-} / \mathrm{I}_{3}^{-}\right)$, where $\mathrm{KI}(1.66 \mathrm{~g})$ and $\mathrm{I}_{2}$ $(0.127 \mathrm{~g}, 0.05 \mathrm{M})$ were mixed in $20 \mathrm{~mL}$ acetonitrile and stirred until homogeneous. The electrolyte solution was stored in a dark and closed bottle. The electrolyte variation was carried out by adding MPII ionic liquid with various concentrations of $0.3,0.4$, and $0.5 \mathrm{M}$. The electrolytes were determined their viscosity, density, $\mathrm{pH}$, and ionic conductivity.

Assembling of DSSCs. DSSCs were prepared by doctor blading using TEC7 FTO-covered glass as follows. $\mathrm{TiO}_{2} / \mathrm{MKA}$ paste and plastisol paste were deposited on FTO glass with $1 \mathrm{~cm}^{2}$ active side forming photoanode and cathode separately. The photoanode was heated in the furnace at $450{ }^{\circ} \mathrm{C}$ for $30 \mathrm{~min}$, while the cathode was heated at $400^{\circ} \mathrm{C}$ for $5 \mathrm{~min}$. Photoanodes were immersed in sensitizer solution $(\mathrm{Bx}, \mathrm{Zn}-\mathrm{Bx}$, and $\mathrm{Cu}-\mathrm{Bx})$ concentrated of $5 \mathrm{~g} / \mathrm{L}$ (in acetone solvent) for $24 \mathrm{~h}$. Furthermore, one drop of electrolyte was added to the photoanode, then covered with a cathode to form a layer like a sandwich. Each cell was tested for performance (Isc and Voc) using a scientific multimeter of 6.5 digits Agilent 34461A. The light source used in the test is a $500 \mathrm{~W}$ halogen lamp. The test conditions are carried out with variations in light intensity of $0-1000 \mathrm{~W} / \mathrm{m}^{2}$.

\section{- RESULTS AND DISCUSSION}

\section{Characteristics of $\mathrm{Bx}, \mathrm{Zn}-\mathrm{Bx}$, and $\mathrm{Cu}-\mathrm{Bx}$}

The TLC analysis (as seen in Fig. 2) shows changes in $\mathrm{Rf}$ after reacting bixin with metal precursors for $60 \mathrm{~min}$. $\mathrm{R}_{\mathrm{f}}$ values' differences are due to the bonding of $\mathrm{Zn}^{2+}$ and $\mathrm{Cu}^{2+}$ to $\mathrm{Bx}$ molecules, which affects the resulting product polarity. The $\mathrm{Rf}$ values of $\mathrm{Bx}, \mathrm{Zn}-\mathrm{Bx}$, and $\mathrm{Cu}-\mathrm{Bx}$ are $0.31,0.73$, and 0.26 , respectively, indicating that the $\mathrm{Zn}-\mathrm{Bx}$ and $\mathrm{Cu}-\mathrm{Bx}$ had been formed with polarity properties $\mathrm{Bx}-\mathrm{Cu}>\mathrm{Bx}>\mathrm{Bx}-\mathrm{Zn}$. This polarity can be influenced by the ion electronegativity of the $\mathrm{Cu}^{2+}(1.90)$, which is greater than $\mathrm{Zn}^{2+}$ (1.65).

The conjugated double bond system constitutes the light-absorbing chromophore of bixin, resulting in a 


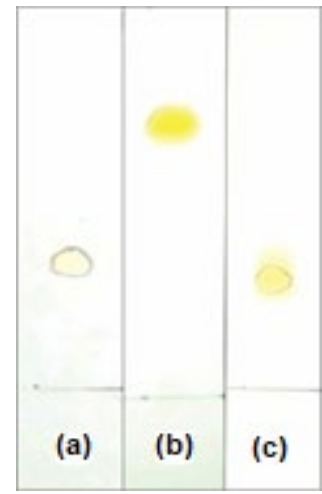

Fig 2. Thin layer chromatogram of $\mathrm{Bx}(\mathrm{a}), \mathrm{Zn}-\mathrm{Bx}(\mathrm{b})$, and $\mathrm{Cu}-\mathrm{Bx}(\mathrm{c})$

strong absorption band above $400 \mathrm{~nm}$, as seen in Fig. 3 . Based on this figure, there are three characteristic peaks for $\mathrm{Bx}$ at 488,459 , and $430 \mathrm{~nm}$. The nine conjugated double bonds influence the absorption spectra in the wavelength range above $400 \mathrm{~nm}$ on the Bx molecule. The peaks at the 488 and $459 \mathrm{~nm}$ wavelengths show an electron transition from $\pi$ to $\pi^{*}$, which comes from the $\mathrm{C}=\mathrm{C}$ conjugated double bond [8]. In contrast, the peak at $430 \mathrm{~nm}$ occurs due to the electron transition from $\mathrm{n}$ to $\pi^{*}$, originating from the carbonyl group $(\mathrm{C}=\mathrm{O})[8,17]$.

The UV-Vis absorption band of $\mathrm{Zn}-\mathrm{Bx}$ coincides with the $\mathrm{Bx}$, while the absorption band of $\mathrm{Cu}-\mathrm{Bx}$ tends to shift towards a lower wavelength (hypsochromic) to $3 \mathrm{~nm}$. The hydroxyl substitution of the carboxylate or ester group in $\mathrm{Bx}$ (as a ligand) interacting with the metal does not affect their chromophore group. Consequently, it will not affect the resulting absorption spectra [18]. The slightly blue shift occurs probably due to the transfer of electrons from the ligand ion to the metal [19]. The charge transfer in the $\mathrm{Cu}-\mathrm{Bx}$ and $\mathrm{Zn}-\mathrm{Bx}$ complexes is most likely derived from the transfer of charge from metal to ligand (Metal to Ligand Charge Transfer or MLCT). The interaction between $\mathrm{Bx}$ and $\mathrm{Zn}^{2+}$ or $\mathrm{Cu}^{2+}$ can also be identified by the change in the \% III/II ratio (fine spectral structure) in the absorption spectrum, illustrated in Fig. 4 [17]. In this research, the ratios \% III/II of Bx, Zn-Bx, and $\mathrm{Cu}-\mathrm{Bx}$ are $51.89,39.28$, and $15.91 \%$, respectively.

The FTIR spectrum of $\mathrm{Bx}$ (Fig. 5) shows the following bands: at $3183 \mathrm{~cm}^{-1}$ for the $-\mathrm{OH}$ stretching vibration, at 2937,2924 , and $2852 \mathrm{~cm}^{-1}$ for the $\mathrm{H}-\mathrm{C}-\mathrm{H}$ bending vibration, at $1716 \mathrm{~cm}^{-1}$ for the ester $\mathrm{C}=\mathrm{O}$ group,

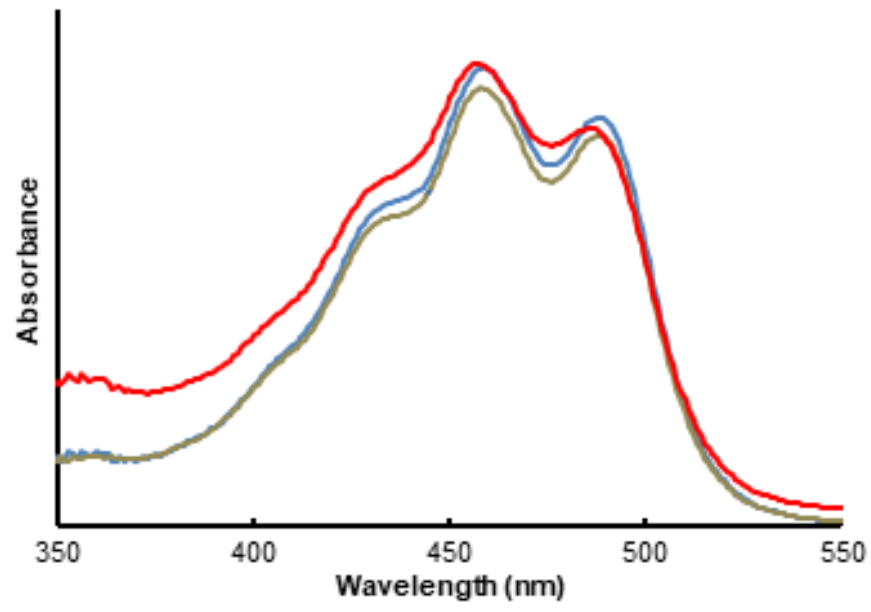

Fig 3. Normalized UV-Vis absorption spectra of $\mathrm{Bx}$ (blue), $\mathrm{Cu}-\mathrm{Bx}$ (red), $\mathrm{Zn}-\mathrm{Bx}$ (grey) in acetone

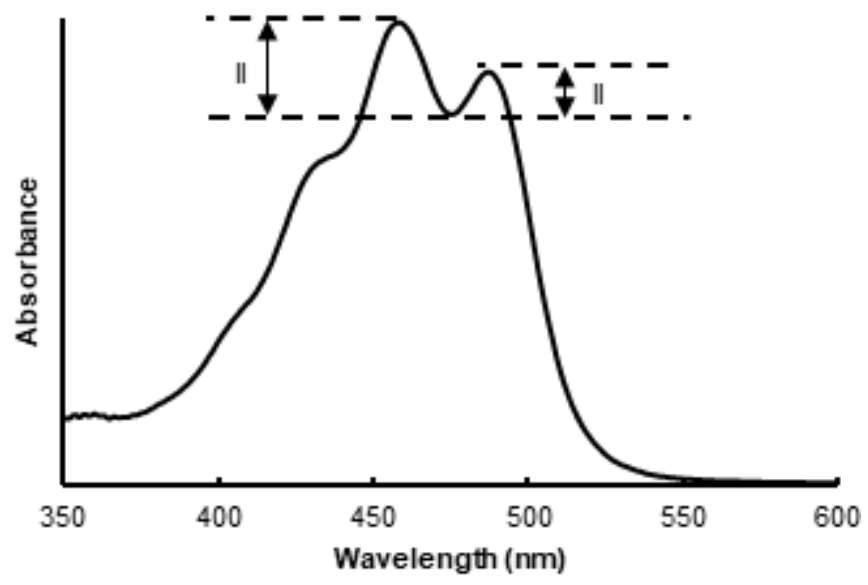

Fig 4. Calculation of \%III/II for a carotenoid [17]

at $1689 \mathrm{~cm}^{-1}$ for the carboxylic $\mathrm{C}=\mathrm{O}$ group, at $1608 \mathrm{~cm}^{-1}$ for the $-\mathrm{OH}$ bending vibration, at 1563 and $1518 \mathrm{~cm}^{-1}$ for the alkene $\mathrm{C}=\mathrm{C}$ stretching vibration, at $1379 \mathrm{~cm}^{-1}$ for $\mathrm{C}-\mathrm{H}$ bending vibration of the methyl groups, at 1288 and $1255 \mathrm{~cm}^{-1}$ for the $\mathrm{C}=\mathrm{O}$ stretching vibration of the ester functional group, at $1160 \mathrm{~cm}^{-1}$ for the symmetric and asymmetric vibrations of the $\mathrm{C}-\mathrm{O}-\mathrm{C}$ ester group, at $1011 \mathrm{~cm}^{-1}$ as the asymmetric $\mathrm{C}-\mathrm{H}$ bending vibration, at $728 \mathrm{~cm}^{-1}$ indicated methylene oscillating vibrations of cis-carotenoid. The FTIR analysis results in agreement with Rahmalia et al. [20] and Lóránd et al. [21] that presented FTIR analysis for cis-bixin compounds.

FTIR spectra of $\mathrm{Zn}-\mathrm{Bx}$ and $\mathrm{Cu}-\mathrm{Bx}$ do not show any significant differences compared to Bx. However, the -OH carboxylate group absorption band became wider, accompanied by a decrease in the absorption peak 

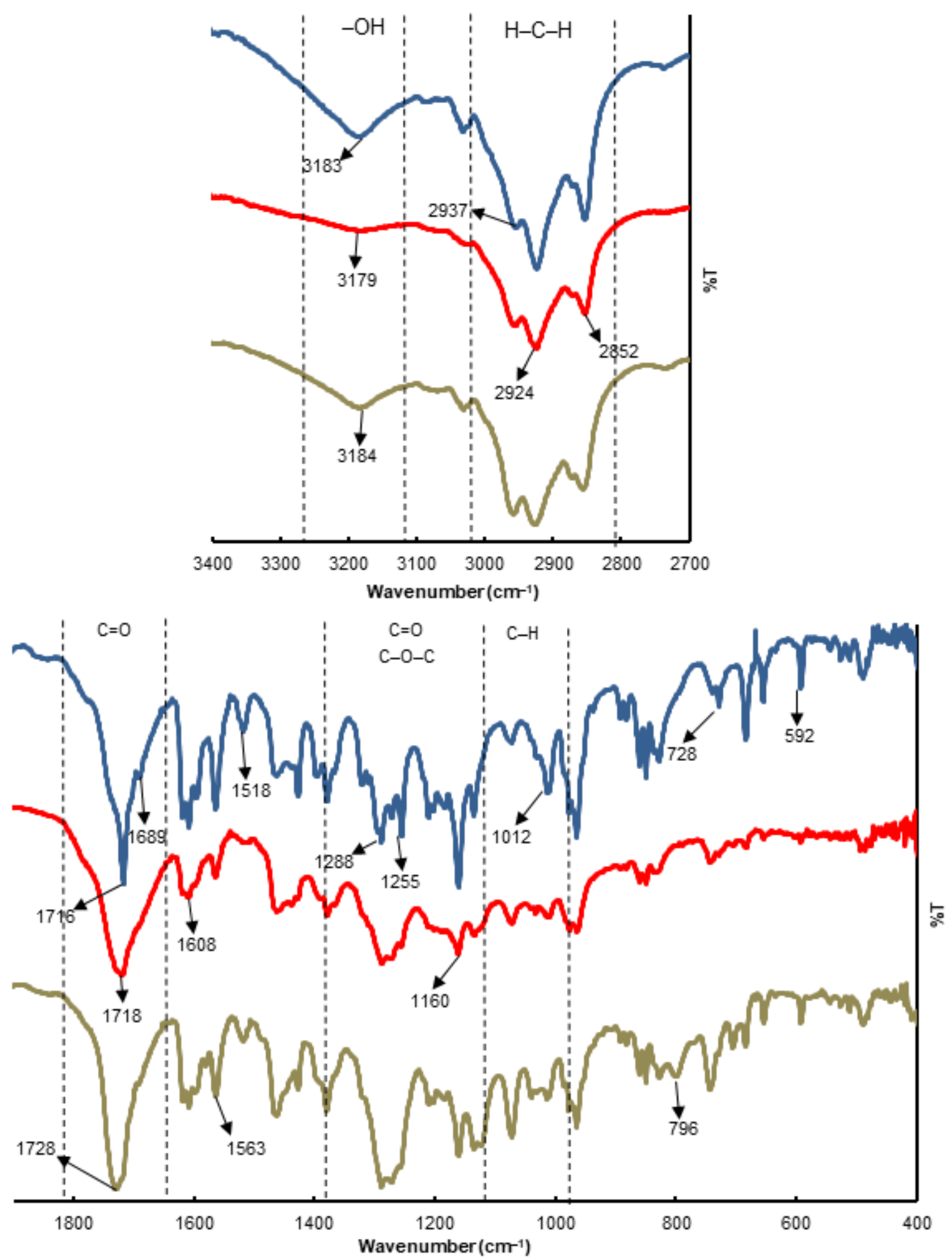

Fig 5. FTIR spectra of $\mathrm{Bx}$ (blue), $\mathrm{Cu}-\mathrm{Bx}$ (red), and $\mathrm{Zn}$-Bx (grey)

intensity. There is a shift to the lower wavenumber for the $\mathrm{Cu}$-Bx complex $\left(3179 \mathrm{~cm}^{-1}\right)$ and the longer wavenumber for the $\mathrm{Zn}-\mathrm{Bx}$ complex at $\left(3184 \mathrm{~cm}^{-1}\right)$ as compared to $\mathrm{Bx}$ $\left(3183 \mathrm{~cm}^{-1}\right)$. Tayyari et al. [22] postulated that a stronger hydrogen bond would show a wider absorption band accompanied by a decrease in absorption intensity. The 
ester group's $\mathrm{C}=\mathrm{O}$ absorption band undergoes a shift to a larger wavenumber, which for $\mathrm{Bx}-\mathrm{Cu}$ and $\mathrm{Bx}-\mathrm{Zn}$ show bands at 1718 and $1728 \mathrm{~cm}^{-1}$, respectively, as compared to Bx $\left(1716 \mathrm{~cm}^{-1}\right)$. The absorption bands at 1288 and $1255 \mathrm{~cm}^{-1}$ are observed to overlap into a wide peak. There were also decreases in the intensities of vibration peaks of the $\mathrm{C}-\mathrm{O}-\mathrm{C}$ ester group at $1160 \mathrm{~cm}^{-1}$ and $\mathrm{C}-\mathrm{H}$ bending vibration at $1011 \mathrm{~cm}^{-1}$. These phenomena indicated that the metal-bixin complex occurs due to the interaction between the ester groups of bixin and the metal [23-24]. According to FT-IR analysis data, the mechanism of complex formation is predicted as given in Fig. 6.

\section{Characteristics of the $\mathrm{KI}-\mathrm{I}_{2}$ Electrolyte with Various MPII Concentrations}

Table 1 shows the characteristics of the $\mathrm{KI}_{2} \mathrm{I}_{2}$ electrolyte with various concentrations of MPII. The greater the MPII concentration added leads to higher density and viscosity values. This phenomenon is due to the increasing number of ion pairs formed by free ions moving randomly in the medium. MPII can form $\mathrm{MPI}^{+}$ and $\mathrm{I}^{-}$ions. This is in good agreement with Chowdhury et al. [25], who investigated the effect of tetrabutylammonium iodide (TBAI) concentrations in the KI- $\mathrm{I}_{2}$ electrolyte system in a polyacetonitrile (PAN) based gel electrolyte. They reported that the higher concentration of TBAI added caused the free ion density of $\mathrm{TBA}^{+}$and $\mathrm{I}^{-}$to increase.

The addition of MPII in the KI- $\mathrm{I}_{2}$ electrolyte system increased the viscosity value almost two times. Although the increase in viscosity causes a decrease in fluid velocity and the rate of electrolyte diffusion, which can affect the transport of electrons in the electrolyte, it can decrease evaporation rate and prevent leakage electrolyte system from cells [26]. The addition of MPII<smiles>COC(=O)/C=C/C(C)=C\C=C\C(C)=C\C=C\C=C(C)\C=C\C=C(C)\C=C\C(=O)OC</smiles><smiles>COC(=O)/C=C/C(C)=C\C=C\C(C)=C\C=C\C=C(C)\C=C\C=C(C)\C=C\C(=O)O</smiles>

Fig 6. Prediction of the mechanism of complex formation 
Table 1. The results of the electrolyte analysis

\begin{tabular}{lrccc}
\hline \multicolumn{1}{c}{ Electrolytes $^{*}$} & $\mathrm{KI}^{2} \mathrm{I}_{2}$ & $\mathrm{KI}^{2} \mathrm{I}_{2} / \mathrm{MPII} 0.3 \mathrm{M}$ & $\mathrm{KI}^{-} \mathrm{I}_{2} / \mathrm{MPII} 0.4 \mathrm{M}$ & $\mathrm{KI}^{-\mathrm{I}_{2}} / \mathrm{MPII} 0.5 \mathrm{M}$ \\
\hline$\rho\left(\mathrm{g} \mathrm{cm}^{-3}\right)$ & 0.82 & 0.87 & 0.88 & 0.88 \\
$\eta(\mathrm{mPa} \mathrm{s})$ & 0.27 & 0.46 & 0.48 & 0.49 \\
$\mathrm{pH}$ & 2.39 & 3.00 & 3.17 & 3.37 \\
$\mathrm{~K}\left(\mathrm{mS} \mathrm{cm}^{-1}\right)$ & 11.14 & 0.02 & 20.44 & 20.46 \\
\hline
\end{tabular}

${ }^{\star} \rho=\operatorname{density}\left(\mathrm{g} \mathrm{cm}^{-3}\right), \eta=\operatorname{viscosity}(\mathrm{mPa} \mathrm{s}), \mathrm{k}=$ ionic conductivity $\left(\mathrm{mS} \mathrm{cm}^{-1}\right)$

did not have a significant effect on the $\mathrm{pH}$ of the electrolyte.

The ionic conductivity of the $\mathrm{KI}_{2} \mathrm{I}_{2}$ electrolyte without MPII was $11.14 \mathrm{mS} \mathrm{cm}^{-1}$. The addition of $0.3 \mathrm{M}$ MPII in the $\mathrm{KI}^{-\mathrm{I}_{2}}$ electrolyte system significantly decreased the conductivity values. However, adding 0.4 and 0.5 M MPII significantly increased the viscosity values to 20.44 and $20.46 \mathrm{mS} \mathrm{cm}^{-1}$, respectively. MPII is an ionic liquid (IL) that increases the electron transport from electrolytes. These results are consistent with the research conducted by Shing et al. [27]. They reported that the addition of MPII in poly (ethylene oxide) polymer electrolyte (PEO) could increase the conductivity of electrons in the electrolyte. However, the excessive concentration MPII addition does not significantly affect the conductivity value and can even reduce the conductivity due to the ion aggregation process in the electrolyte. Therefore, based on the density, viscosity, and conductivity values, the optimum concentration of MPII added in the $\mathrm{KI}-\mathrm{I}_{2}$ electrolyte system in this study is $0.4 \mathrm{M}$.

\section{DSSC Performance}

Fig. 7 shows the relationship between Voc, Isc, and the maximum energy conversion efficiency to the light intensity of the DSSCs using the KI- $\mathrm{I}_{2}$ electrolyte without MPII. Voc is the maximum voltage available from a solar cell that occurs at zero current, while Isc is the current through the solar cell when the voltage across the solar cell is zero. They are the key parameters that govern the attainable power from a DSSC. The maximum energy conversion efficiency describes the performance of a DSSC, how much solar energy (photons) can be converted into electrical energy without considering the value of the fill factor. It is the ratio between power generated by DSSC and the power of the light sources.

As shown in Fig. 7, Voc and Isc increase logarithmically with light intensity. All DSSC have the
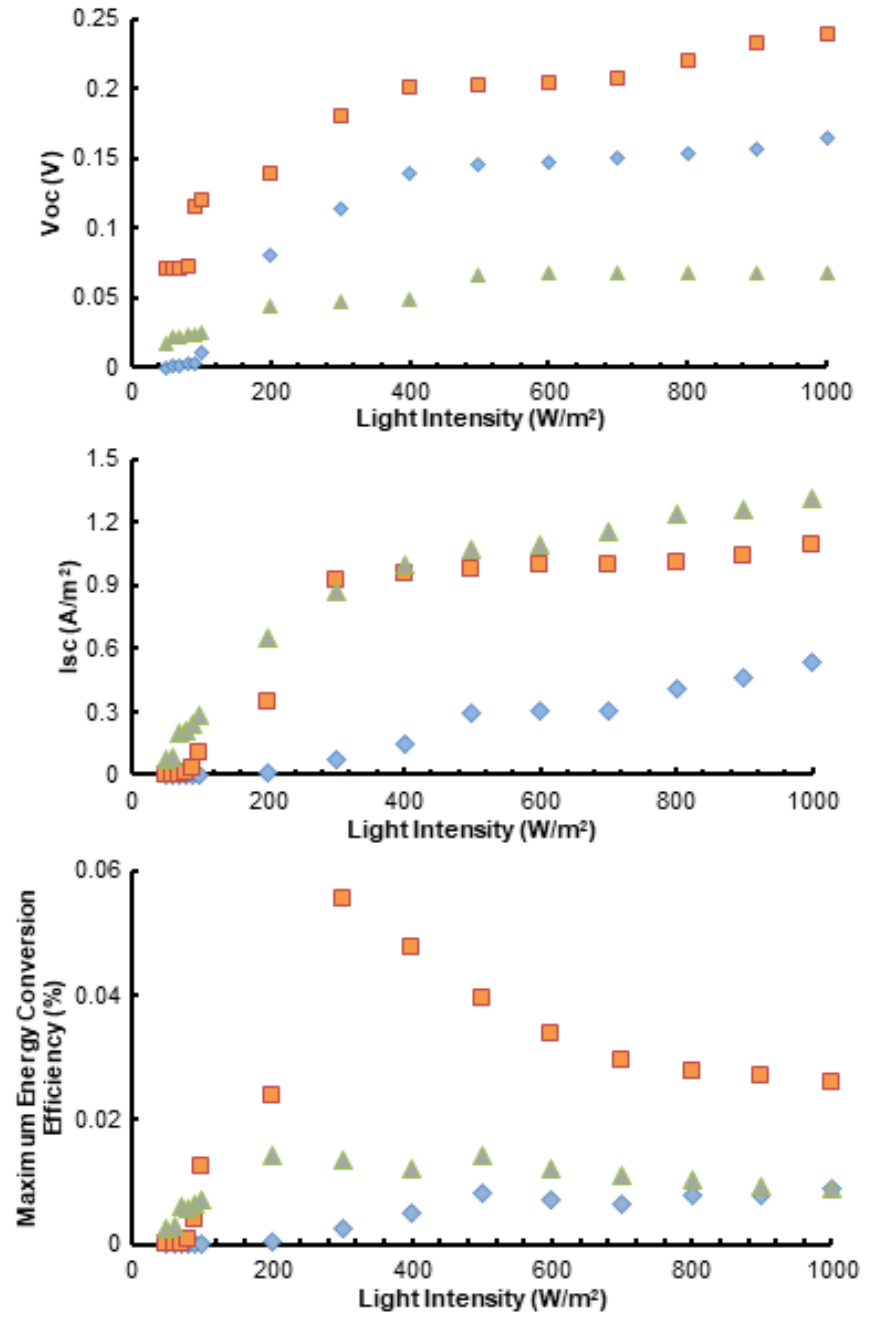

Fig 7. Performance parameter of DSSCs using $B x(\bullet)$, $\mathrm{Bx}-\mathrm{Zn}(\boldsymbol{\bullet})$, and $\mathrm{Bx}-\mathrm{Cu}(\boldsymbol{\Delta})$ as sensitizer and $\mathrm{KI}-\mathrm{I}_{2}$ electrolyte system

same curve pattern. However, under various light intensities, $\mathrm{Zn}-\mathrm{Bx}$ and $\mathrm{Cu}-\mathrm{Bx}$-based DSSCs showed higher Voc values than pure Bx-based DSSC. Voc is given by the difference of the electrons Fermi level in the $\mathrm{TiO}_{2}$ and the electrolyte redox potential [28]. In this work, the presence of metal in the dye, which then covers 
the semiconductor surface, may increase the semiconductor's electrons' Fermi level. $\mathrm{Zn}$ is a better redox catalyst than $\mathrm{Cu}$, causing the highest $\mathrm{Voc}$ value under various light intensities. $\mathrm{Zn}-\mathrm{Bx}$ and $\mathrm{Cu}-\mathrm{Bx}$-based DSSCs show higher Isc values than those based on pure $\mathrm{Bx}$. This phenomenon indicated that $\mathrm{Zn}^{2+}$ and $\mathrm{Cu}^{2+}$ in the bixin molecule could increase the number of excited electrons from dye sensitizer and promote the rapid injection of these excited electrons into the semiconductor conduction band.

Based on Fig. 7, the maximum energy conversion efficiency of DSSCs using $\mathrm{KI}^{-} \mathrm{I}_{2}$ electrolyte occurs under a light intensity of $300 \mathrm{~W} / \mathrm{m}^{2}$ with the values of $0.003,0.055$, and $0.013 \%$ for $\mathrm{Bx}, \mathrm{Zn}-\mathrm{Bx}$, and $\mathrm{Cu}-\mathrm{Bx}$ based DSSCs, respectively. The maximum energy conversion efficiency of DSSCs decreases under light intensity higher than $300 \mathrm{~W} / \mathrm{m}^{2}$. This is due to increased cell temperature that may evaporate liquid electrolyte $\mathrm{KI}-\mathrm{I}_{2}$ and/or provoke charge recombination between dye sensitizer and semiconductor.

The effect of MPII $0.4 \mathrm{M}$ addition in the KI- $\mathrm{I}_{2}$ liquid electrolyte system on the performance of the DSSC based on $\mathrm{Bx}, \mathrm{Zn}-\mathrm{Bx}$, and $\mathrm{Cu}-\mathrm{Bx}$ has also been investigated. The relationship between $\mathrm{Voc}$, Isc, and the maximum energy conversion efficiency to the light intensity with MPII $0.4 \mathrm{M}$ addition can be seen in Fig. 8. The addition of MPII to the KI-I $\mathrm{I}_{2}$ electrolyte system significantly affects the Isc values. For all DSSC, Isc increases almost linearly with increasing light intensity, indicated that MPII plays a role in increasing the electrolyte stability. These results are in good agreement with Ramesh [29], who reported that MPII could increase Isc due to increased ionic conductivity of iodide ions or ion transfer in the MPI+ $\mathrm{I}^{-}$ electrolyte. The $\mathrm{K}^{+}$ions can intercalate into the semiconductor layer, causing a positive shift in the conduction band and increasing the charge injection rate. MPII is high ionic hopping, which can accelerate the dissociation initiation of $\mathrm{KI}$.

The stability of the DSSCs performance under high light intensity is supported by the increase in the value of electrolyte viscosity due to MPII. Leakage and evaporation of liquid electrolytes were prevented. DSSC that used $\mathrm{Zn}$ $\mathrm{Bx}$ as a sensitizer even shows good performance under
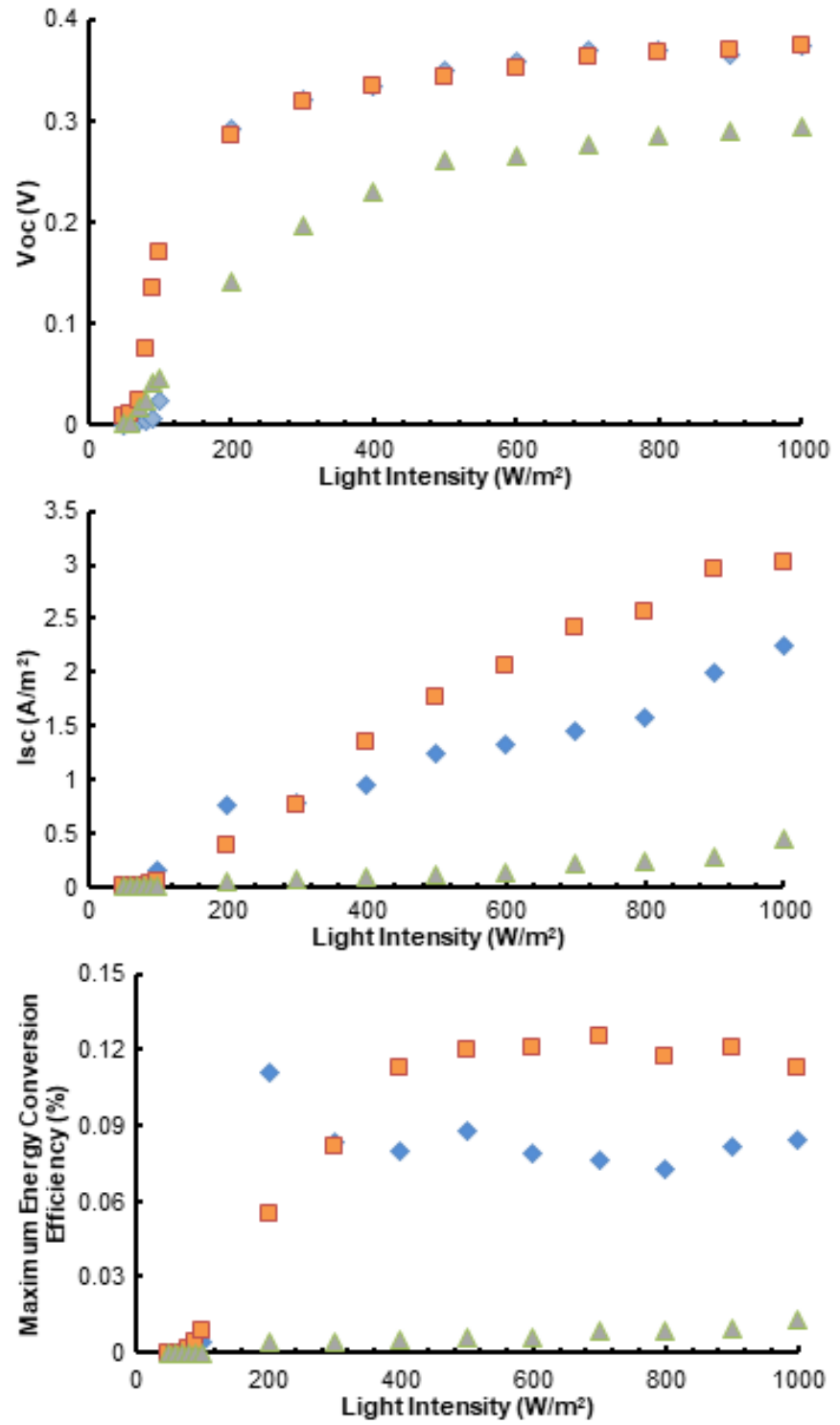

Fig 8. Performance parameters of DSSCs using $\mathrm{Bx}(\bullet)$, $\mathrm{Bx}-\mathrm{Zn}(\boldsymbol{\bullet})$, and $\mathrm{Bx}-\mathrm{Cu}(\boldsymbol{\Delta})$ as sensitizer and $\mathrm{KI}-\mathrm{I}_{2}+\mathrm{MPII}$ $0.4 \mathrm{M}$ electrolyte system

$700 \mathrm{~W} / \mathrm{m}^{2}$ of light intensity. Under this condition, the maximum energy conversion efficiency shows values of $0.076,0.125$, and $0.008 \%$ for $\mathrm{Bx}, \mathrm{Zn}-\mathrm{Bx}$, and $\mathrm{Cu}-\mathrm{Bx}-$ based DSSCs, respectively. This phenomenon proves that complexion bixin with $\mathrm{Zn}^{2+}$ can improve the stability and performance of bixin. $\mathrm{Zn}^{2+}$ is a metal ion that is not oxidized.

\section{- CONCLUSION}

The metal-bixin complexes were successfully synthesized due to the interaction between the ester 
groups of bixin and the metal. Complexing bixin on metals has a positive impact on increasing bixin's stability and performance as a sensitizer. The presence of MPII in the $\mathrm{KI}-\mathrm{I}_{2}$ electrolyte system also produces several advantages, including an increase in the electrolyte's conductivity, density, and viscosity. A synergistic work was observed between the Zn-bixin complex and the KI-I ${ }_{2}$-MPII $0.4 \mathrm{M}$ electrolyte system in the DSSC with a maximum energy conversion efficiency of 0.125 under $700 \mathrm{~W} / \mathrm{m}^{2}$ light intensity and no significant decrease when the light intensity increased. Although there are some problems with natural DSSCs, such as their stability and durability, this research's results can solve the disadvantages. Finally, with the advance of technology, their good application prospect will be apparent.

\section{- ACKNOWLEDGMENTS}

This study received financial support from the Ministry of Research Technology and the Higher Education Republic of Indonesia (KEMENRISTEK DIKTI) through the National Competitive Research (217/SP2H/LT/DRPM/2019).

\section{- REFERENCES}

[1] Gong, J., Sumathy, K., Qiao, Q., and Zhou, Z., 2017, Review on dye-sensitized solar cells (DSSCs): Advanced techniques and research trends, Renewable Sustainable Energy Rev., 68, 234-246.

[2] Mariotti, N., Bonomo, M., Fagiolari, L., Barbero, N., Gerbaldi, C., Bella, F., and Barolo, C., 2020, Recent advances in eco-friendly and cost-effective materials towards sustainable dye-sensitized solar cells, Green Chem., 22 (21), 7168-7218.

[3] Prabavathy, N., Shalini, S., Balasundaraprabhu, R., Velauthapillai, D., Prasanna, S., and Muthukumarasamy, N., 2017, Enhancement in the photostability of natural dyes for dye-sensitized solar cell (DSSC) applications: A review, Int. J. Energy Res., 41 (10), 1372-1396.

[4] Semalti, P., and Sharma, S.N., 2020, Dye-sensitized solar cells (DSSCs) electrolytes and natural photosensitizers: A review, J. Nanosci. Nanotechnol., 20 (6), 3647-3658.
[5] Gómez-Ortíz, N.M., Vázquez-Maldonado, I.A., Pérez-Espadas, A.R., Mena-Rejón, G.J., AzamarBarrios, J.A., and Oskam, G., 2010, Dye-sensitized solar cells with natural dyes from achiote seeds, Sol. Energy Mater. Sol. Cells, 94 (1), 40-44.

[6] Hiendro, A., Hadary, F., Rahmalia, W., and Wahyuni, N., 2012, Enhanced performance of bixin-sensitized $\mathrm{TiO}_{2}$ solar cells with activated kaolinite, Int. J. Eng. Res. Innov., 4 (1), 40-44.

[7] Hug, H., Bader, M., Mair, P., and Glatzel, T., 2013, Biophotovoltaics: Natural pigments in dyesensitized solar cells, Appl. Energy, 115, 216-225.

[8] Rahmalia, W., Fabre, J.F., Usman, T., and Mouloungui, Z., 2014, Aprotic solvents effect on the UV-visible absorption spectra of bixin, Spectrochim. Acta, Part A, 131, 455-460.

[9] Kabir, F., Sakib, S.N., and Matin, N., 2019, Stability study of natural green dye based DSSC, Optik, 181, 458-464.

[10] de Sousa Lobato, K.B., Paese, K., Forgearini, J.C., Guterres, S.S., Jablonski, A., and de Oliveira Rios, A., 2015, Evaluation of stability of bixin in nanocapsules in model systems of photosensitization and heating, LWT Food Sci. Technol., 60 (1), 8-14.

[11] Cortez, R., Luna-Vital, D.A., Margulis, D., and de Mejia, E.G., 2016, Natural pigments: Stabilization methods of anthocyanins for food applications, Compr. Rev. Food Sci. Food Saf., 16 (1), 180-198.

[12] Rahmalia, W., 2016, Paramètres de Performances de Photo-électrodes de $\mathrm{TiO}_{2} /$ Kaolinite et d'Electrolyte à base de Carbonates Biosourcés dans la Cellule Solaire Sensibilisée par la Bixine, Dissertation, Institut National Polytechnique de Toulouse, France.

[13] Soldatović, T., 2018, "Mechanism of interactions of zinc(II) and copper(II) complexes with small biomolecules" in Basic Concepts Viewed from Frontier in Inorganic Coordination Chemistry, IntechOpen, London, UK.

[14] Lo, K.K.W., 2017, Inorganic and Organometallic Transition Metal Complexes with Biological 
Molecules and Living Cells, $1^{\text {st }}$ Ed., Academic Press, Cambridge, Massachusetts, USA.

[15] Shi, L.Y., Chen, T.L., Chen, C.H., and Cho, K.C., 2013, Synthesis and characterization of a gel-type electrolyte with ionic liquid added for dye-sensitized solar cells, Int. J. Photoenergy, 2013, 834184.

[16] Khanmirzaei, M.H., Ramesh, S., and Ramesh K., 2015, Hydroxypropyl cellulose-based non-volatile gel polymer electrolytes for dye-sensitized solar cell applications using 1-methyl-3-propylimidazolium iodide ionic liquid, Sci. Rep., 5, 18056.

[17] Britton, G., 1995, "UV/visible Spectroscopy" in Carotenoids, Vol. 1B: Spectroscopy, Eds., Britton, G, Liaaen-Jensen, S, and Pfander, H., Birkhäuser Verlag, Basel, Boston and Berlin.

[18] Popova, A.V., 2017, Spectral characteristics and solubility of $\beta$-carotene and zeaxanthin in different solvents, C. R. Acad. Bulg. Sci., 70 (1), 53-60.

[19] Zebib, B., Mouloungui, Z., and Noirot, V., 2010, Stabilization of curcumin by complexation with divalent cations in glycerol/water system, Bioinorg. Chem. Appl., 2010, 292760.

[20] Rahmalia, W., Fabre, J.F., and Mouloungui, Z., 2015, Effects of cyclohexane/acetone ratio on bixin extraction yield by accelerated solvent extraction method, Procedia Chem., 14, 455-464.

[21] Lóránd, T., Molnar, P., Deli, J., and Tóth, G., 2002, FT-IR study of some seco- and apocarotenoids, $J$. Biochem. Biophys. Methods, 53 (1-3), 251-258.

[22] Tayyari, S.F., Vakili, M., Nekoei, A.R., Rahemi, H., and Wang, Y.A., 2007, Vibrational assignment and structure of trifluorobenzoylacetone: A density functional theoretical study, Spectrochim. Acta, Part A, 66 (3), 626-636.

[23] Rahmalia, W., Fabre, J.F., Usman, T., and Mouloungui, Z., 2020, Preparation of ammonia dealuminated metakaolinite and its adsorption against bixin, Indones. J. Chem., 20 (4), 791-800.

[24] Yang, C., and Wöll, C., 2017, IR spectroscopy applied to metal oxide surfaces: Adsorbate vibrations and beyond, Adv. Phys.: X, 2 (2), 373-408.

[25] Chowdhury, F.I., Buraidah, M.H., Arof, A.K., Mellander, B.E., and Noor, I.M., 2020, Impact of tetrabutylammonium, iodide and triiodide ions conductivity in polyacrylonitrille based electrolyte on DSSC performance, Sol. Energy, 196, 379-388.

[26] Gu, P., Yang, D., Zhu, X., Sun, H., Wangyang, P., Li, J., and Tian, H., 2017, Influence of electrolyte proportion on the performance of dye-sensitized solar cells, AIP Adv., 7 (10), 105219.

[27] Singh, P.K., Kim, K.W., and Rhee, H.W., 2009, Ionic liquid (1-methyl 3-propyl imidazolium iodide) with polymer electrolyte for DSSC application, Polym. Eng. Sci., 49 (5), 862-865.

[28] Raga, R., Barea, E.M., and Fabregat-Santiago, F., 2012, Analysis of the origin of open circuit voltage in dye solar cells, J. Phys. Chem. Lett., 3 (12), 1629-1634.

[29] Ng, H.M., Ramesh, S., and Ramesh, K., 2015, Efficiency improvement by incorporating 1methyl-3-propylimidazolium iodide ionic liquid in gel polymer electrolytes for dye-sensitized solar cells, Electrochim. Acta, 175, 169-175. 